\title{
Effect of Changing Front Top Roller Pressure of Drafting Zone of a Ring Frame on the Quality of Cotton-Flax Blended Yarn
}

\author{
Md. Masum Reza ${ }^{1 *}$, Mohammad Nayemul Islam², Sharif Ahmed1, Mohammad Naim Hassan³ \\ ${ }^{1}$ Department of Yarn Engineering, Bangladesh University of Textiles, Dhaka, Bangladesh \\ ${ }^{2}$ Department of Research \& Development, NZ Textile Limited, Dhaka, Bangladesh \\ ${ }^{3}$ Department of Textile Engineering, Khulna University of Engineering \& Technology, Dhaka, Bangladesh \\ Email: ^masumreza@ye.butex.edu.bd
}

How to cite this paper: Reza, Md.M., Islam, M.N., Ahmed, S. and Hassan, M.N. (2022) Effect of Changing Front Top Roller Pressure of Drafting Zone of a Ring Frame on the Quality of Cotton-Flax Blended Yarn. Journal of Textile Science and Technology, 8, 25-34.

https://doi.org/10.4236/jtst.2022.81003

Received: January 1, 2022

Accepted: February 7, 2022

Published: February 10, 2022

Copyright $\odot 2022$ by author(s) and Scientific Research Publishing Inc. This work is licensed under the Creative Commons Attribution International License (CC BY 4.0).

http://creativecommons.org/licenses/by/4.0/

\begin{abstract}
Pressure applied on the top roller of drafting zone is a vital factor on which the quality of ultimate yarn depends. Drafting zone is needed to reduce the mass per unit length of input material. Appropriate contact of top rollers with bottom rollers is necessary to ensure proper drafting. In this paper, the effects of different front top roller pressure of drafting zone on the quality of $20 \mathrm{Ne}$ cotton-flax blended yarns $(\mathrm{C}: \mathrm{L}=45: 55)$ were studied. It was observed that a higher pressure value gives a lower co-efficient of mass variation, imperfections, hairiness and higher evenness, tenacity, elongation properties.
\end{abstract}

\section{Keywords}

Arm Pressure, Drafting Zone, Jingwei F-1520, Unevenness, Imperfection, Tenacity, Blended Yarn

\section{Introduction}

The arm pressure loads of roller drafting system in ring frame machine have a great influence on the yarn properties to produce a high quality yarn. Fiber friction, the roller setting and top arm pressure have a major impact on the nature of fiber movement during the drafting stages [1]. The ratio of the surface speed of succeeding rollers to that of the preceding rollers is defined as a draft. Here, the rollers run at higher speeds from the back- to the front-rollers and the fibre strand comparatively becomes thinner by drafting. In a ring spinning machine mostly 3-over-3 roller with a double apron drafting system is used to produce yarn from roving. The bottom rollers are made of steel and the top rollers are 
covered with synthetic rubber. The bottom rollers are positively driven and the top rollers are run by frictional surface contacts of the bottom rollers. The top rollers must be pressed with relatively high force over bottom rollers by spring load, air pressure or magnetically. The drafting force is needed to draft the fibre strand which gets from the loading of the pressure of top rollers by pressure arm [2].

Various research works have been carried out on the impacts of roller settings on various aspects during roller drafting [3] [4] [5]. The optimal changes on bottom roller setting, roller pressure and break draft at draw frame drafting system, showed that the yarn unevenness, coefficient of variation, end breakages rate, yarn hairiness, imperfections were reduced significantly and yarn strength was also improved [6]. Recently, Yuemin et al. [7] studied the effects of block gauge, pressure on the front rollers and break draft on a modified drafting system based on the ring spinning frame to produce 18.2 tex cotton yarn.

A number of research works also carried out on drafting force and its impact on the properties of yarn [8] [9] [10] [11] [12]. Qasim et al. [13] studied the online drafting force and its variability at draw frame drafting system and found that the minimum variability of drafting force ensures better fiber distribution along the sliver length resulting in a lower irregularity of sliver at certain break draft ratios.

In another, Qasim et al. [14] analyzed the draftometer data of dynamic drafting force and its variability with respect to the short fiber content of cotton carded sliver.

Mohammad et al. [15] proposed an experimental design to analyze the effects of the total draft, break draft, distance between the aprons (Clips) and production roller pressure to spin a 20 Tex blend yarn of PES (70\%)/CV (30\%) blend ratio. Results showed that the best quality of yarn was obtained under a total draft of 38, 1.2 break draft, $2.8 \mathrm{~mm}$ distance between of aprons and the maximum pressure of the production top roller (18 daN).

With the increase of top arm pressure the fiber friction area increases, which assists in better controlling the fiber flow in the drafting zone but in case of too high pressure, deteriorates the yarn quality. Previous studies showed that most of the works on top arm pressure are applied to cotton and synthetic yarns but till now little is known about the effects of top arm pressure on cotton-flax blended yarns.

In this project, we used a ring frame machine (jingwei F-1520) where spring loaded pressure arm was used. Particular amount of load is applied on each top rollers of drafting zone in every weighting system. Some pressure disc red, green and black are used to represent particular amount of pressure in kgs. The main object of this study was to investigate the yarn quality parameters by changing the front top roller pressure of drafting zone to optimize the yarn quality.

\section{Materials and Methods}

\subsection{Materials}

In this study Pima cotton, Chad cotton and Indian flax fibers were used to pro- 
duce $20 \mathrm{Ne}$ cotton-flax blended yarn. The average flax fiber length was $40 \mathrm{~mm}$ and average fineness was 32 denier. The fiber properties of raw cottons were tested by USTER HVI (High Volume Instruments)-1000 Machine which are given in Table 1.

\subsection{Methods}

The cotton fibers and flax fiber were mixed on a Trutzschler blow room line with a mixing ratio of 25:20:55 for pima cotton, chad cotton and Indian flax fiber accordingly. Chute mat was produced at end of the blow room line. Then the card slivers (109 grains/yard) were produced through a carding machine (Trutzschler BC-05) and breaker draw frame (SBD-40) to produce first drawn sliver (90 grains/yard). First drawn slivers were then processed through a finisher draw frame and produced finisher drawn sliver ( 90 grains/yard). Then $0.73 \mathrm{Ne}$ roving were produced through speed frame (Toyota FL-16) and finally $20 \mathrm{Ne}$ cotton-flax blended yarns were produced in ring frame machine (Jingwei F-1520). To investigate the effects of different front top roller pressure, color of pressure disc were changed. Red, green and black colors of pressure disc represent 18, 14 and 10kg pressure on the front top roller respectively. To study the front top roller pressure, back and middle top roller pressure were kept constant (Table 2). Others parameters of ring frame were used to produce yarns are also given in Table 3.

We used 8 spindles where the total number of spindle of this ring frame was 1008. Produced yarns are collected from these eight spindles by changing front top roller pressures were $18,14,10 \mathrm{kgs}$ respectively and tested on an USTER TESTER-5 machine for testing count, evenness, co-efficient of mass variation, imperfection, hairiness, CSP, tenacity and elongation. From each combination 8 readings were tested. The irregularity, hairiness and imperfections of all the yarns were tested on an Uster Tester-5 at $400 \mathrm{~m} /$ minute for 1 minute. Tenacity (RKM) were conducted through Mesdan lab strength tester with CRE principle with 500 $\mathrm{mm}$ sample length and clamp speed $500 \mathrm{~mm} / \mathrm{min}$. Count Strength Product (CSP) were also done with CRE principle through Elestretch (Mesdan lab).

Table 1. Fiber properties of Pima and Chad cotton.

\begin{tabular}{cccccccccccccccc}
\hline $\begin{array}{c}\text { Sl } \\
\text { No. }\end{array}$ & SCI & $\begin{array}{c}\text { Mst } \\
\%\end{array}$ & Mic & Mat & $\begin{array}{c}\text { UHML } \\
\text { mm }\end{array}$ & $\begin{array}{c}\text { UI } \\
\%\end{array}$ & $\begin{array}{c}\text { SFC } \\
\%\end{array}$ & $\begin{array}{c}\text { Str } \\
\text { g/tex }\end{array}$ & $\begin{array}{c}\text { Elg } \\
\%\end{array}$ & Rd & +b & $\begin{array}{c}\text { Colour } \\
\text { grade }\end{array}$ & $\begin{array}{c}\text { TrAr } \\
\%\end{array}$ & $\begin{array}{c}\text { TrCnt } \\
\text { Cnt/gm }\end{array}$ & $\begin{array}{c}\text { Trash } \\
\text { grade }\end{array}$ \\
\hline USA Pima Cotton & 200 & 4.6 & 4.12 & 0.86 & 35.38 & 86 & 5.3 & 43.2 & 7.2 & 72.7 & 10.9 & $33-1$ & 0.12 & 17 & 1 \\
Chad Cotton & 151 & 6.9 & 4.62 & 0.87 & 30.48 & 83.7 & 7.2 & 34.6 & 6.4 & 74.9 & 11.2 & $23-1$ & 0.34 & 14 & 3 \\
\hline
\end{tabular}

Table 2. Combination of top rollers pressures of drafting zone.

\begin{tabular}{cccc}
\hline Roller & Pressure for Red & Pressure for Green & Pressure for Black \\
\hline Front & 18 & 14 & 10 \\
Middle & 16 & 16 & 16 \\
Back & 14 & 14 & 14 \\
\hline
\end{tabular}




\section{Result}

The detailed yarn quality parameters corresponding to given front top roller pressures in drafting zone of ring frame are given in Tables 4-6 shows the different yarn characteristics and their correlation with the chosen variables. The values of top roller pressures for all the yarn characteristics were well correlated with all the chosen variables.

Correlation of yarn quality parameters with the changing of front top roller pressures of drafting zone of ring frame are graphically presented below.

\section{Discussion}

Figures 1-7 show that unevenness, co-efficient of mass variation, thin place, thick place, neps, imperfection, hairiness values decreases and Figures 8-10 represents tensile properties of yarns i.e. CSP, elongation and tenacity (RKM) increases with increasing front top roller pressure. In almost all the cases highest

Table 3. Parameters of ring frame to produce $20 \mathrm{Ne}$ cotton-flax blended yarns.

\begin{tabular}{cc}
\hline Parameter & Value \\
\hline Break draft & 1.52 \\
Front draft & 18.78 \\
Total draft & 28.55 \\
T.P.I & 23.04 \\
Twist multiplier & 5.15 \\
Traveler number & $1 / 0$ \\
Spacer & $4 \mathrm{~mm}$ \\
Roller gauge & $44 \mathrm{~mm} \times 54 \mathrm{~mm}$ \\
Spindle speed & 9500 \\
\hline
\end{tabular}

Table 4. Characteristics of yarns for applying $10 \mathrm{~kg}$ pressure on the front top roller of drafting zone.

\begin{tabular}{ccccccccccc}
\hline No. & U\% & CVm\% & $\begin{array}{c}\text { Thin } \\
-50 \% / k m\end{array}$ & $\begin{array}{c}\text { Thick } \\
+50 \% / k m\end{array}$ & $\begin{array}{c}\text { Neps } \\
+200 \% / k m\end{array}$ & IPI & H & CSP & $\begin{array}{c}\text { Elongation } \\
\%\end{array}$ & $\begin{array}{c}\text { RKM } \\
(\mathrm{CN} / \mathrm{Tex})\end{array}$ \\
\hline 1 & 23.53 & 30.17 & 2590 & 3803 & 6855 & 13,248 & 6.68 & 1720 & 5.40 & 13.44 \\
2 & 23.61 & 30.51 & 2865 & 3993 & 7258 & 14,116 & 6.75 & 1725 & 5.22 & 12.36 \\
3 & 23.91 & 30.72 & 2823 & 3990 & 6918 & 13,731 & 6.61 & 1700 & 5.16 & 12.29 \\
4 & 22.88 & 29.66 & 2575 & 3525 & 6963 & 13,063 & 6.75 & 1698 & 5.10 & 12.15 \\
5 & 24.08 & 31.29 & 3288 & 4078 & 7878 & 15,244 & 6.77 & 1735 & 5.04 & 11.91 \\
6 & 24.06 & 30.99 & 2968 & 4000 & 7203 & 14,171 & 6.81 & 1738 & 4.92 & 11.84 \\
7 & 23.34 & 30.03 & 2588 & 3873 & 6838 & 13,299 & 6.64 & 1745 & 4.92 & 11.64 \\
8 & 23.56 & 30.44 & 2468 & 3723 & 6598 & 12,789 & 6.39 & 1739 & 4.80 & 11.57 \\
Mean & 23.62 & 30.48 & 2770.63 & 3873.13 & 7063.88 & $13,707.63$ & 6.68 & 1725.00 & 5.07 & 12.15 \\
\hline
\end{tabular}


Table 5. Characteristics of yarns for applying $14 \mathrm{~kg}$ pressure on the front top roller of drafting zone.

\begin{tabular}{ccccccccccc}
\hline No. & $\mathrm{U} \%$ & $\mathrm{CVm} \%$ & $\begin{array}{c}\text { Thin } \\
-50 \% / \mathrm{km}\end{array}$ & $\begin{array}{c}\text { Thick } \\
+50 \% / \mathrm{km}\end{array}$ & $\begin{array}{c}\text { Neps } \\
+200 \% / \mathrm{km}\end{array}$ & IPI & H & CSP & $\begin{array}{c}\text { Elongation } \\
\%\end{array}$ & $\begin{array}{c}\text { RKM } \\
(\mathrm{CN} / \mathrm{Tex})\end{array}$ \\
\hline 1 & 22.04 & 28.33 & 1835 & 3583 & 6873 & 12,291 & 6.67 & 1804 & 5.40 & 13.48 \\
2 & 23.26 & 30.01 & 2648 & 3843 & 7408 & 13,899 & 6.84 & 1807 & 5.34 & 13.61 \\
3 & 22.62 & 29.19 & 2110 & 3720 & 7008 & 12,838 & 6.7 & 1795 & 5.22 & 12.87 \\
4 & 23.77 & 30.31 & 2795 & 3945 & 7193 & 13,933 & 6.86 & 1800 & 5.15 & 12.87 \\
5 & 21.81 & 27.83 & 1675 & 3405 & 6588 & 11,668 & 6.55 & 1803 & 4.92 & 12.63 \\
6 & 22.49 & 28.67 & 2130 & 3530 & 6928 & 12,588 & 6.8 & 1803 & 4.86 & 12.39 \\
7 & 24.37 & 31.29 & 3253 & 4340 & 7778 & 15,371 & 6.88 & 1815 & 4.80 & 11.74 \\
8 & 23.39 & 30.21 & 2715 & 3868 & 7245 & 13,828 & 6.88 & 1815 & 4.74 & 11.47 \\
Mean & 22.969 & 29.480 & 2395.125 & 3779.250 & 7127.625 & $13,302.000$ & 6.773 & 1805.250 & 5.05 & 12.59 \\
\hline
\end{tabular}

Table 6. Characteristics of yarns for applying $18 \mathrm{~kg}$ pressure on the front top roller of drafting zone.

\begin{tabular}{ccccccccccc}
\hline No. & U\% & CVm\% & $\begin{array}{c}\text { Thin } \\
-50 \% / \mathrm{km}\end{array}$ & $\begin{array}{c}\text { Thick } \\
+50 \% / \mathrm{km}\end{array}$ & $\begin{array}{c}\text { Neps } \\
+200 \% / \mathrm{km}\end{array}$ & IPI & H & CSP & $\begin{array}{c}\text { Elongation } \\
\%\end{array}$ & $\begin{array}{c}\text { RKM } \\
(\mathrm{CN} / \mathrm{Tex})\end{array}$ \\
\hline 1 & 21.7 & 28.22 & 1518 & 3353 & 6295 & 11,166 & 6.79 & 1988 & 6.78 & 15.25 \\
2 & 22.03 & 28.44 & 1455 & 3460 & 6340 & 11,255 & 6.55 & 1989 & 6.78 & 14.70 \\
3 & 22.79 & 29.64 & 2090 & 3730 & 6998 & 12,818 & 6.78 & 2001 & 6.48 & 14.50 \\
4 & 22.54 & 29.44 & 2000 & 3628 & 6508 & 12,136 & 6.56 & 1985 & 6.42 & 14.30 \\
5 & 22.33 & 29.08 & 1848 & 3670 & 6668 & 12,186 & 6.7 & 1990 & 6.36 & 14.30 \\
6 & 22.08 & 28.84 & 1668 & 3335 & 6228 & 11,231 & 6.67 & 1988 & 6.24 & 14.26 \\
7 & 22.65 & 29.59 & 2150 & 3608 & 7000 & 12,758 & 6.74 & 1981 & 6.12 & 14.12 \\
8 & 22.85 & 29.75 & 2140 & 3680 & 6908 & 12,728 & 6.67 & 1982 & 6.06 & 13.51 \\
Mean & 22.371 & 29.125 & 1858.625 & 3558.000 & 6618.125 & $12,034.750$ & 6.683 & 1988.000 & 6.40 & 14.36 \\
\hline
\end{tabular}

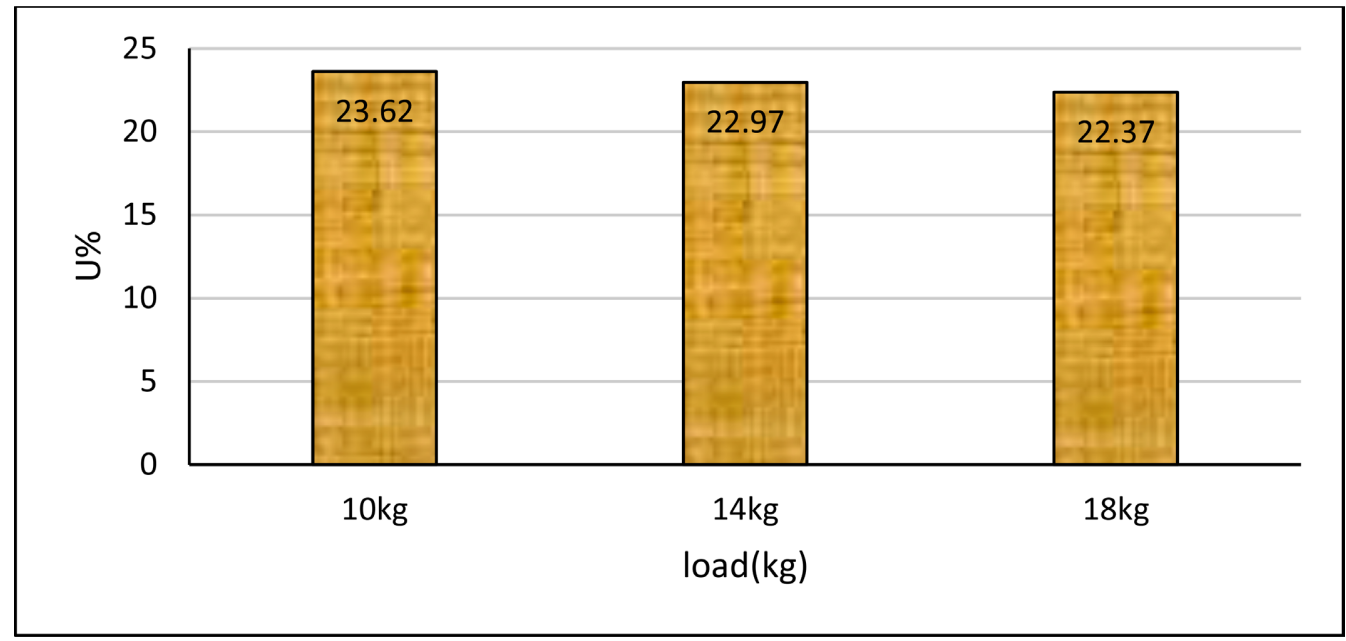

Figure 1. Effects of yarn unevenness on front top roller pressures of drafting zone. 


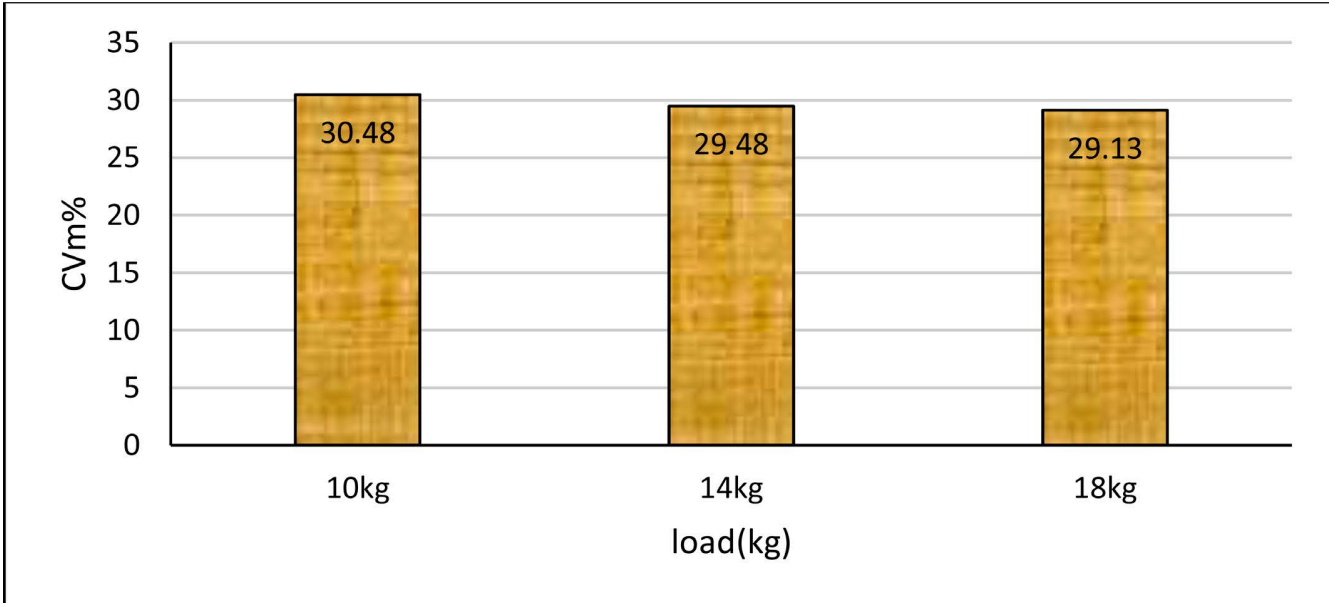

Figure 2. Effects of co-efficient of mass variations of yarns on front top roller pressures of drafting zone.

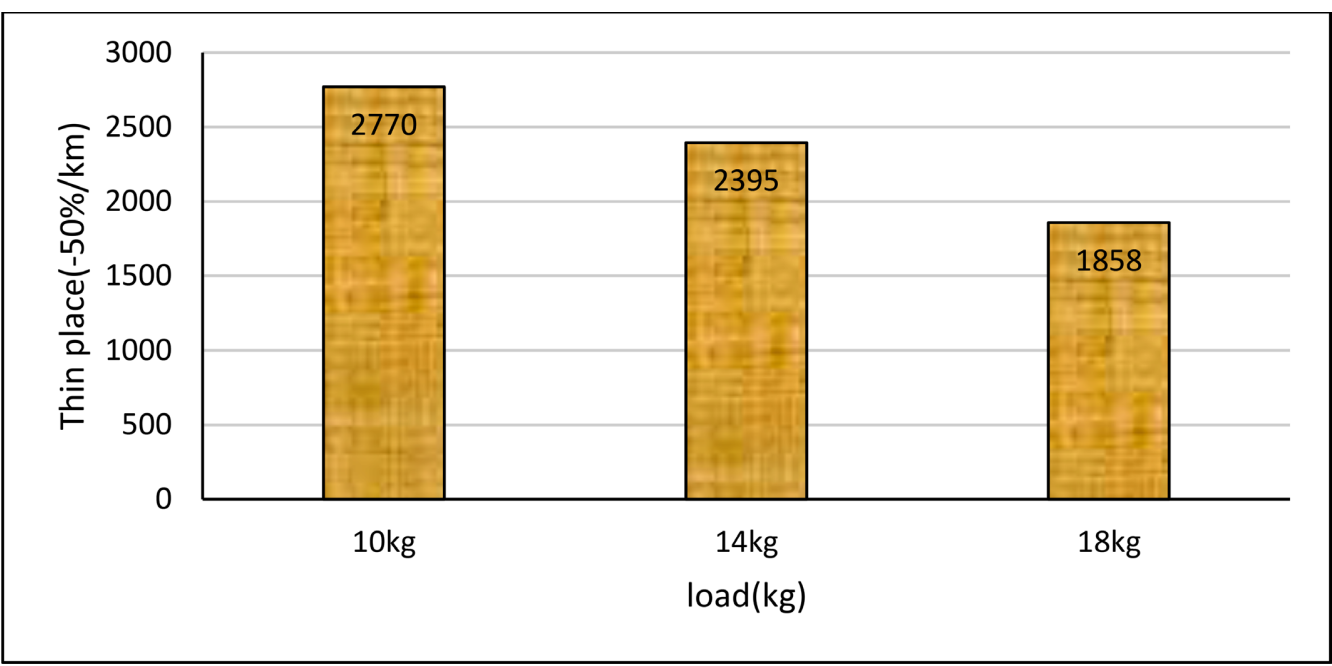

Figure 3. Effects of thin places of yarns on front top roller pressures of drafting zone.

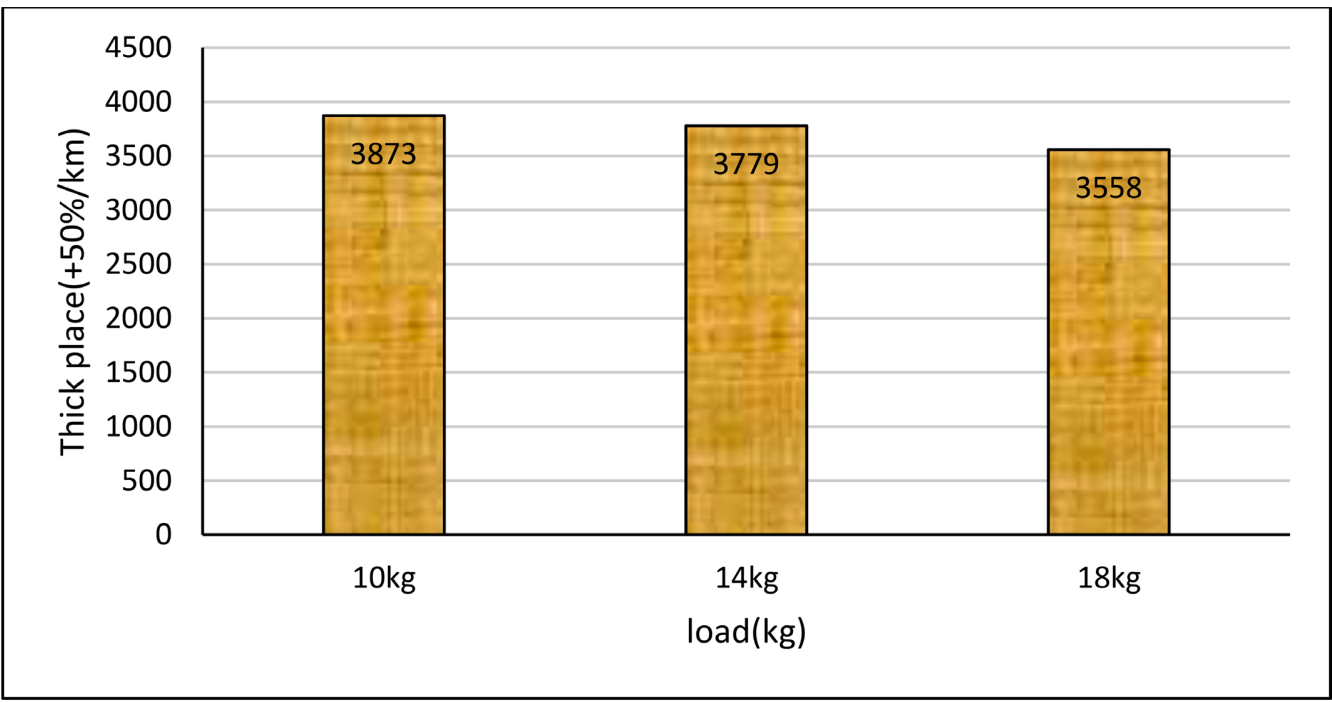

Figure 4. Effects of thick places of yarns on front top roller pressures of drafting zone. 


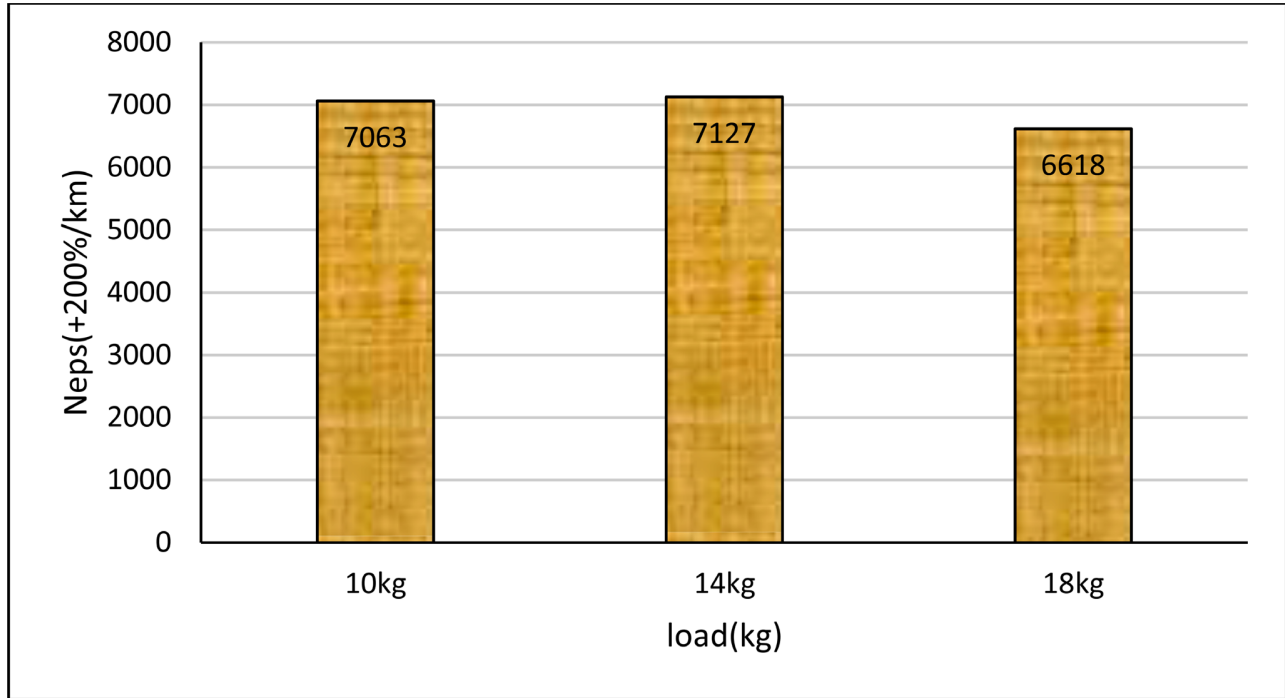

Figure 5. Effects of yarn neps on front top roller pressures of drafting zone.

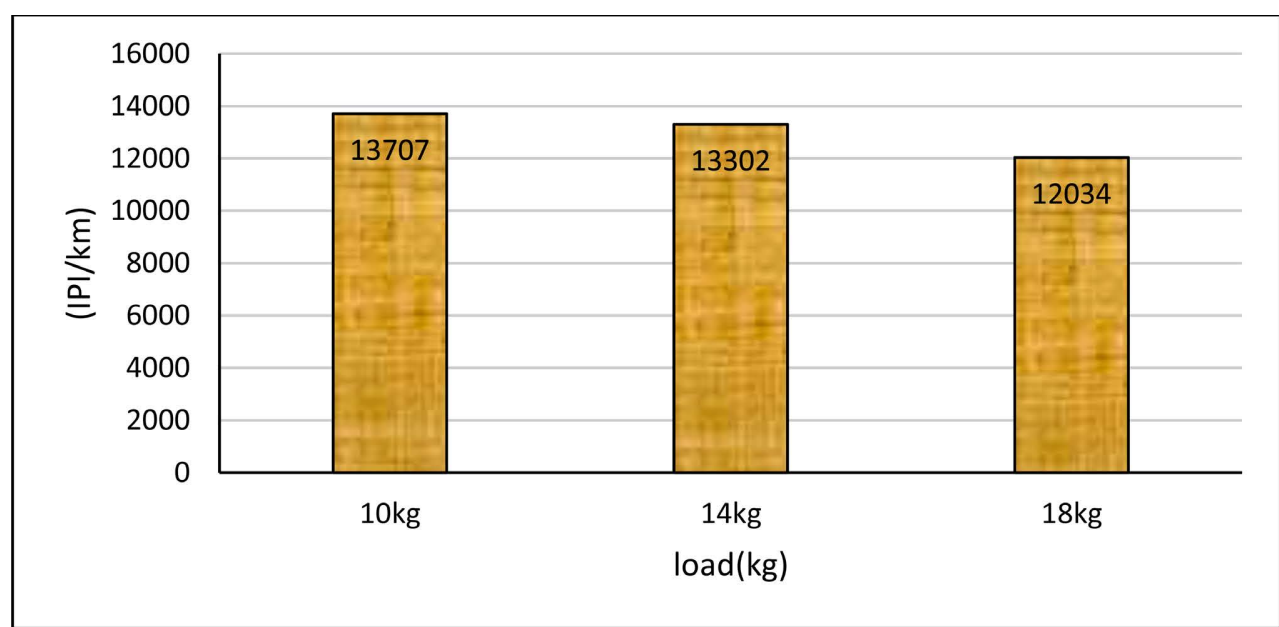

Figure 6. Effects of yarn imperfections on front top roller pressures of drafting zone.

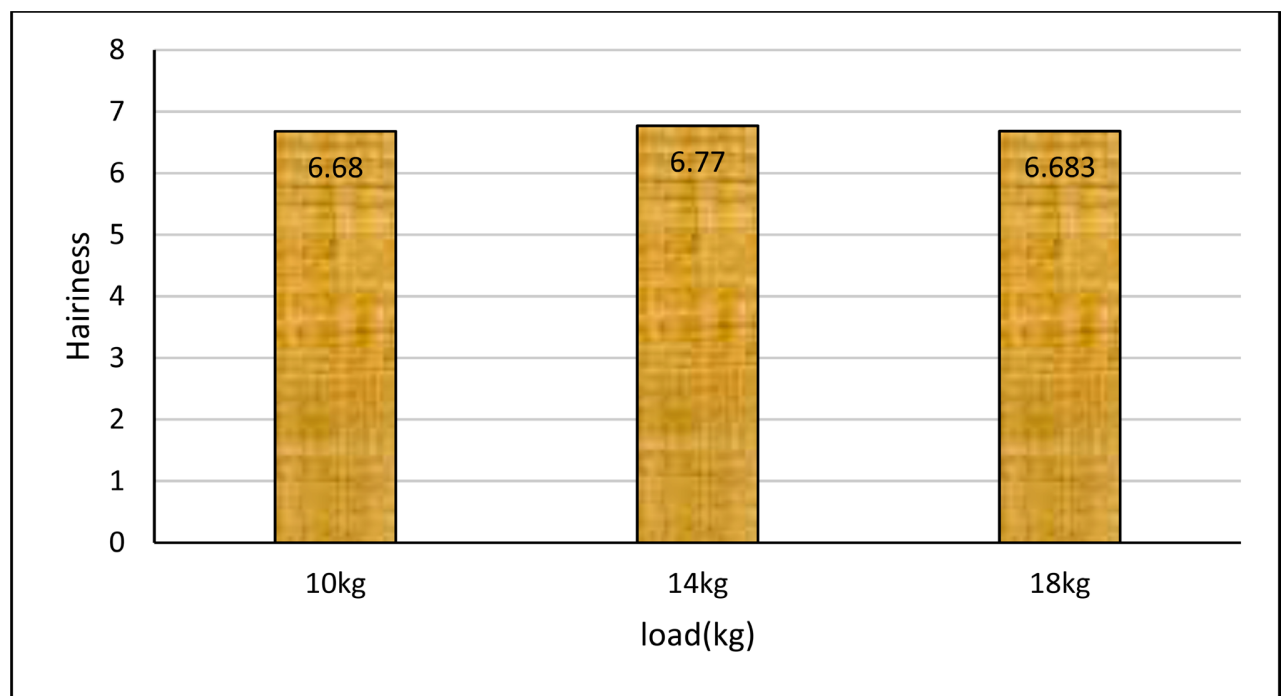

Figure 7. Effects of yarn hairiness on front top roller pressures of drafting zone. 


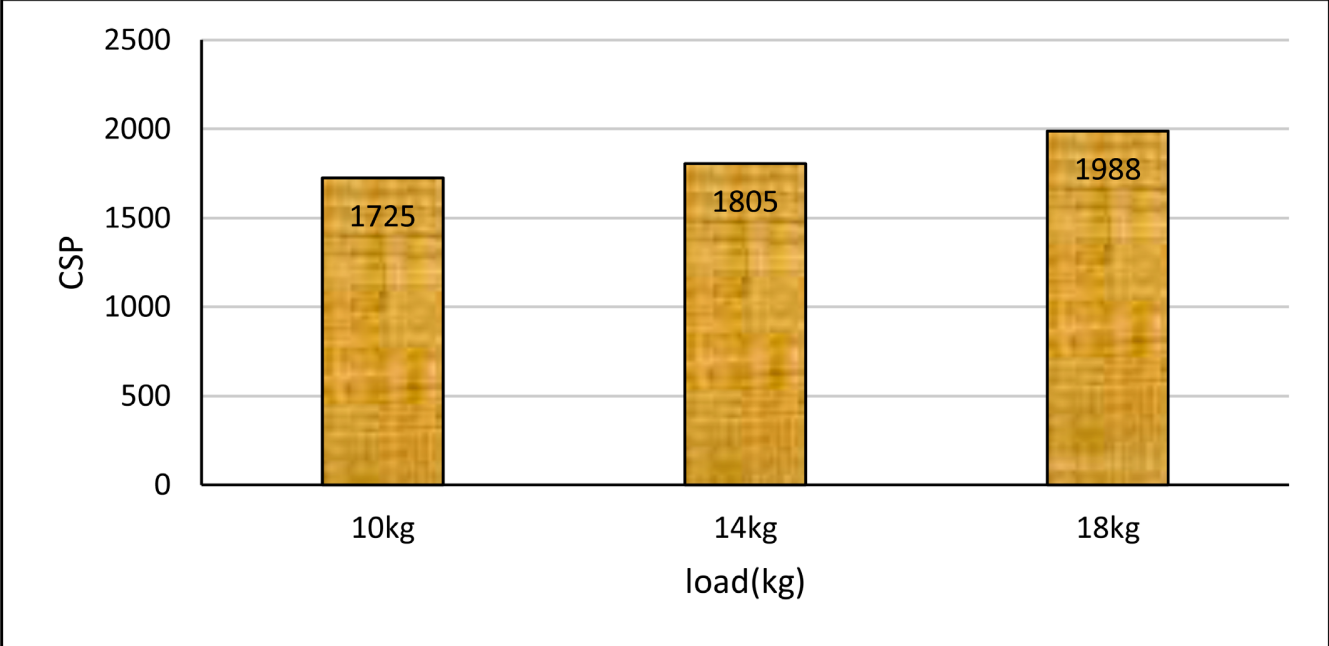

Figure 8. Effects of yarn CSP on front top roller pressures of drafting zone.

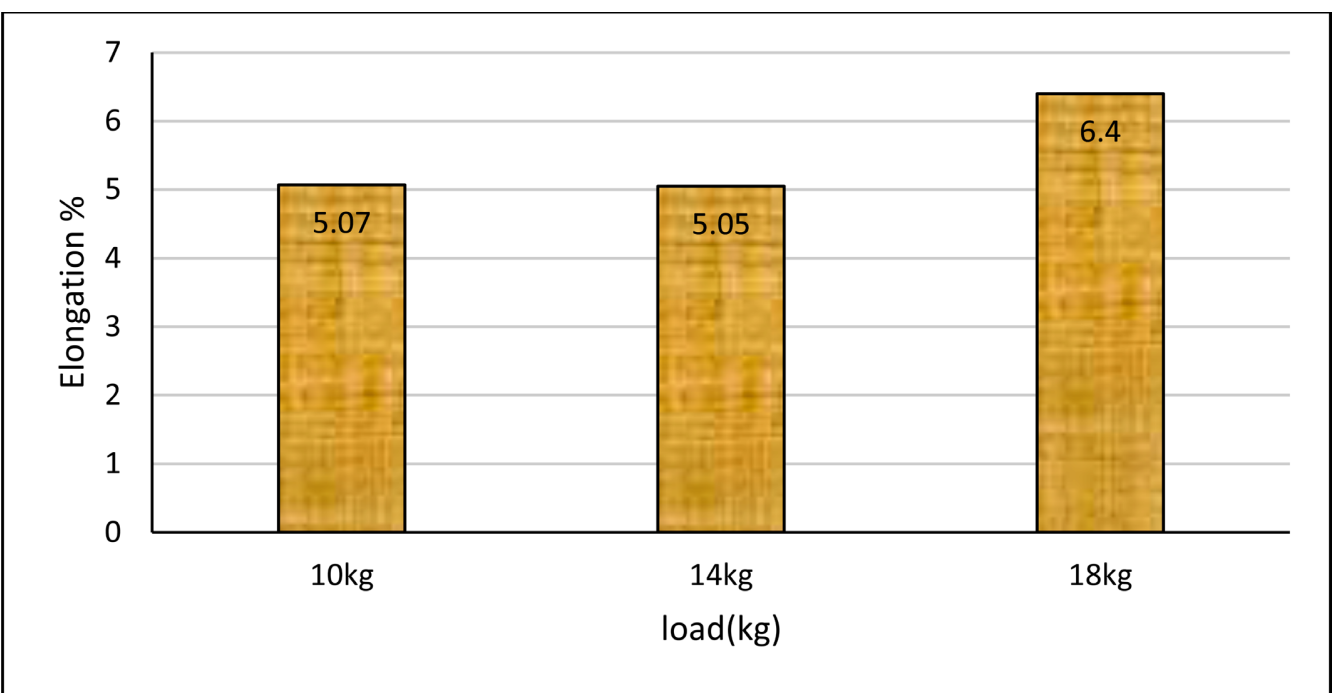

Figure 9. Effects of yarn elongation on front top roller pressures of drafting zone.

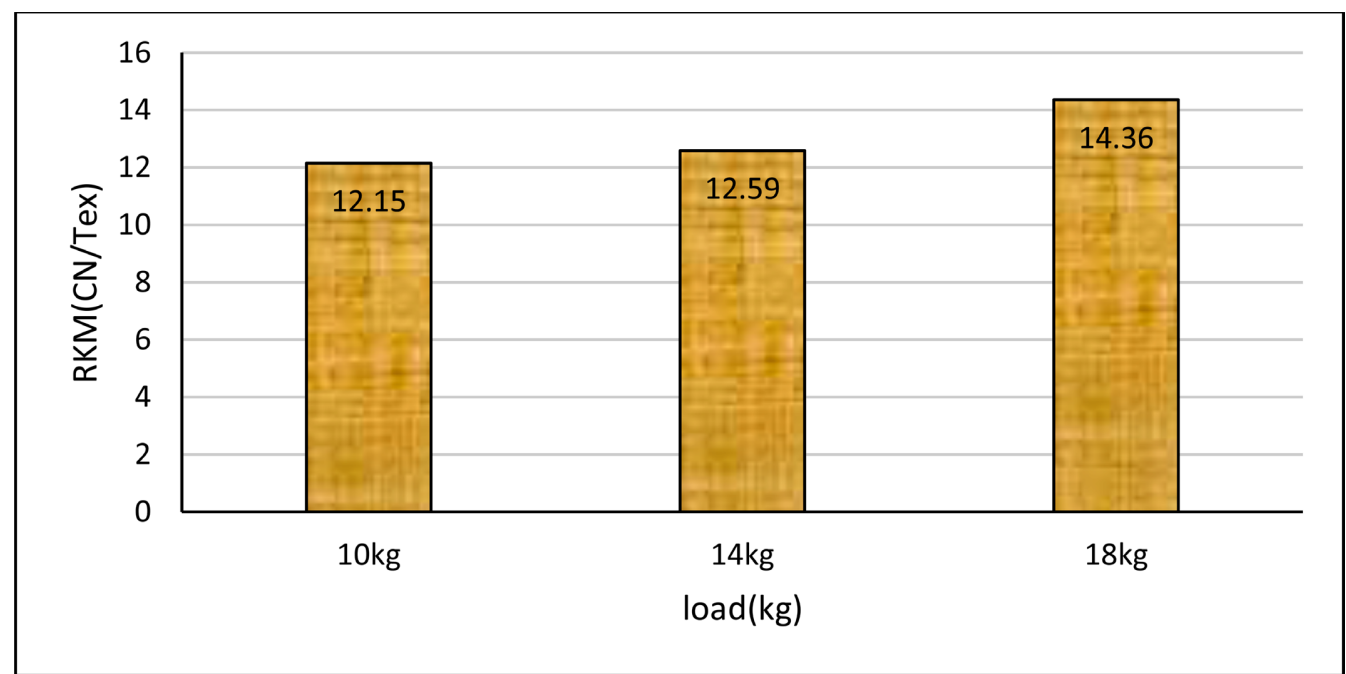

Figure 10. Effects of yarn tenacity on front top roller pressures of drafting zone. 
pressure showed better results (higher evenness and strength).

\section{Conclusion}

The study shows the arm pressure loads of roller drafting system has a great influence on the yarn properties. It was found that the higher value of front top roller pressure gave higher evenness of yarns. Imperfection and hairiness also decrease with the increase of top roller pressure. Tensile properties i.e. yarn tenacity and elongation\% also improved by applying $18 \mathrm{~kg}$ pressure to produce $20 \mathrm{Ne}$ cotton-flax blended yarns.

\section{Acknowledgements}

The authors are extremely thankful to Quality Control Department of NZ Textile Limited for their well co-operation and selfless support to conduct the work.

\section{Conflicts of Interest}

The authors declare no conflicts of interest regarding the publication of this paper.

\section{References}

[1] Ishtiaque, S.M., Das, A. and Niyogi, R. (2006) Optimization of Fiber Friction, Top Arm Pressure and Roller Setting at Various Drafting Stages. Textile Research Journal, 76, 913-921. https://doi.org/10.1177/0040517506067331

[2] Rengasamy, R.S. (2010) Fundamental Principles of Ring Spinning of Yarns. In: Lawrence, C.A., Ed., Advances in Yarn Spinning Technology, Woodhead Publishing, Sawston, Cambridge, 42-78. https://doi.org/10.1533/9780857090218.1.42

[3] Ghosh, G.C. and Bhaduri, S.N. (1962) Dependence of Hook Removal at Drawing on Some Drafting Parameters. Textile Research Journal, 32, 864-866.

https://doi.org/10.1177/004051756203201013

[4] Cavaney, B. and Foster, G.A.R. (1955) 38-The Irregularity of Materials Drafted on Cotton Spinning Machinery and Its Dependence on Draft, Doubling and Roller Setting. Journal of the Textile Institute Transactions, 46, T529-T550. https://doi.org/10.1080/19447027.1955.10750339

[5] Anderson, S.L. and Foster, G.A.R. (1955) 39-The Irregularity of Materials Drafted on Cotton Spinning Machinery and Its Dependence on Draft, Doubling and Roller Setting. Journal of the Textile Institute Transactions, 46, T551-T564. https://doi.org/10.1080/19447027.1955.10750340

[6] Ramasamy, K.M., Duraisamy, R. and Mammo, H. (2019) Improving Yarn Quality by Modification on Drafting Zone Settings of Draw Frame. International Journal of Engineering Trends and Technology, 67, 157-166. https://doi.org/10.14445/22315381/IJETT-V67I11P226

[7] Cui, Y., Song, H., Cheng, L., Deng, W. and Ji, Y. (2021) Experimental Study of a Modified Drafting System Based on the Ring Spinning Frame. Textile Research Journal, 91, 1486-1496. https://doi.org/10.1177/0040517520984977

[8] Das, A., Ishtiaque, S.M. and Kumar, R. (2004) Study on Drafting Force of Roving: Part III-Effect of Process Parameters and Roving Irregularity on Drafting Force Variability. Indian Journal of Fibre and Textile Research, 29, 308-312. 
[9] Das, A., Ishtiaque, S.M. and Kumar, R. (2004) Study on Drafting Force of Roving: Part IV-Correlation between Drafting Force, Roving Strength and Yarn Quality. Indian Journal of Fibre and Textile Research, 29, 313-317.

[10] Olsen, J.S. (1974) Measurement of Sliver Drafting Forces. Textile Research Journal, 44, 852-855. https://doi.org/10.1177/004051757404401105

[11] Su, C.I., Lo, K.J. and Lee, J.Y. (1998) Drafting Force of Fine Denier Polyester Fibers. Textile Research Journal, 68, 559-563. https://doi.org/10.1177/004051759806800803

[12] El-Sharkawy, A.F., Audivert, R. and De Castellar, M.D. (1974) The Relation between the Drafting Force, Draft, and Setting in the Roller-Drafting of Staple-Fibre Slivers. Journal of the Textile Institute, 65, 325-327. https://doi.org/10.1080/00405007408630476

[13] Siddiqui, Q., Abro, Z. and Yu, C. (2015) Study of Drafting Force Variability and Sliver Irregularity at the Break Draft Zone of a Draw Frame. Textile Research Journal, 85, 1465-1473. https://doi.org/10.1177/0040517514563724

[14] Siddiqui, Q., Naeem, M.A. and Ndlovu, L. (2020) A Preliminary Study on the Effect of Short Fiber Content on Drafting Force and Its Variability. Journal of Natural Fibers. https://doi.org/10.1080/15440478.2020.1727816

[15] Hatamvand, M., Mirjalili, S.A., Fattahi, S., Bashir, T. and Skrifvars, M. (2017) Optimum Drafting Conditions of Polyester and Viscose Blend Yarns. Autex Research Journal, 17, 213-218. https://doi.org/10.1515/aut-2016-0016 